\title{
Correction to: Occurrence of polybrominated diphenyl ethers in floor and elevated surface house dust from Shanghai, China
}

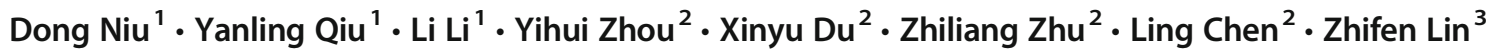

Published online: 30 July 2019

(C) The Author(s) 2019

\section{Correction to: Environmental Science and Pollution Research (2018) 25:18049-18058 https://doi.org/10.1007/s11356-018-1968-4}

The article Occurrence of polybrominated diphenyl ethers in floor and elevated surface house dust from Shanghai, China, written by Dong Niu, Yanling Qiu, Li Li, Yihui Zhou, Xinyu $\mathrm{Du}$, Zhiliang Zhu, Ling Chen and Zhifen Lin, was originally published electronically on the publisher's internet portal (currently SpringerLink) on 24 April 2018 without open access.

With the author(s)' decision to opt for Open Choice the copyright of the article changed on July 2019 to $\odot$ The Author(s) 2019 and the article is forthwith distributed under the terms of the Creative Commons Attribution 4.0 International License (http://creativecommons.org/licenses/by/4.0/), which permits use, duplication, adaptation, distribution and reproduction in any medium or format, as long as you give appropriate credit to the original author(s) and the source, provide a link to the Creative Commons license and indicate if changes were made.

Open Access This article is distributed under the terms of the Creative Commons Attribution 4.0 International License (http://creativecommons. org/licenses/by/4.0/), which permits use, duplication, adaptation, distribution and reproduction in any medium or format, as long as you give appropriate credit to the original author(s) and the source, provide a link to the Creative Commons license and indicate if changes were made.

Publisher's note Springer Nature remains neutral with regard to jurisdictional claims in published maps and institutional affiliations.

The online version of the original article can be found at https://doi.org/ 10.1007/s11356-018-1968-4

Yanling Qiu

ylqiu@tongji.edu.cn

1 Key laboratory of Yangtze River Water Environment, College of Environmental Science and Engineering, Tongji University, Shanghai 200092, China

2 State Key Laboratory of Pollution Control and Resource Reuse, College of Environmental Science and Engineering, Tongji University, Shanghai 200092, China

3 Shanghai Key Laboratory of Chemical Assessment and Sustainability, College of Environmental Science and Engineering, Tongji University, Shanghai 200092, China 